and Documents on the First World War (1914${ }_{19 I} 8$ ). Financing of continued publication is a persistent problem. (3) Monographic studies. It is hoped that henceforth the staff of the Insti- tute, which has been heavily engaged in compilation work, may devote half its time to monographic research on the many problems of modern history awaiting attention.

\title{
The Association for Asian Studies: Summary of the Year 1959-1960
}

\section{Membership}

The year 1959 marked a turning point in the history of the growth of the Association. Under the chairmanship and stimulus of Ward Morehouse, and the active support of a large membership committee located regionally, an active campaign was organized. As a result, the total membership rose dramatically to the highest in the Association's history. As of March I, the number was 1,532 , in contrast to a membership of I,I 24 on March I, I959.

The total of 1,532 included the following classification of members: 5 honorary, I I life,

\section{Professional Field}

History

Political Science and

International Relations

Lang., Lit., and Linguistics ......... 106

Anthropology ................. 105

Far Eastern Studies .............. $\quad \mathbf{2 8}$

Economics .................... 82

Fine Arts $\ldots \ldots \ldots \ldots \ldots \ldots \ldots .35$

Geography $\ldots \ldots \ldots \ldots \ldots \ldots \ldots 4^{8}$

Library Work ............... I7

Philosophy and Religion .......... 47

Education $\ldots \ldots \ldots \ldots \ldots \ldots \ldots . .22$

Law $\ldots \ldots \ldots \ldots \ldots \ldots \ldots \ldots \ldots$

Psychology $\ldots \ldots \ldots \ldots \ldots \ldots \ldots \ldots .6 \%$

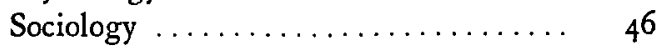

Medicine $\ldots \ldots \ldots \ldots \ldots \ldots \ldots$ I

Indology $\ldots \ldots \ldots \ldots \ldots \ldots \ldots \ldots$

Natural Sciences ............... 3

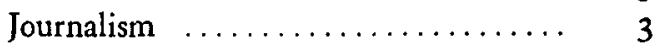

Unknown $\ldots \ldots \ldots \ldots \ldots \ldots \ldots \ldots, 296$
57 supporting, I,06I regular, 364 student (a new category), 34 associate. Of the present membership, 1,343 reside in the United States and 155 are foreign members. Membership increased in all geographical areas of the United States, and particularly noteworthy is the sharp rise registered in such states as Vermont, North Carolina, and Arizona where new Asian studies programs were begun. Largest representation was from the Middle Atlantic states (354) and the Pacific states (28I). The following figures reflect the field, status, and area of primary interest of the membership (excluding associate members):

\section{Professional Status}

Faculty $\ldots \ldots \ldots \ldots \ldots \ldots \ldots \ldots, \mathbf{6}_{44}$

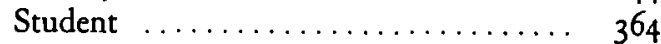

Government $\ldots \ldots \ldots \ldots \ldots \ldots \ldots$ I19

Others ..................... 185

Unknown $\ldots \ldots \ldots \ldots \ldots \ldots \ldots, \quad 186$

Total $\overline{1,498}$

Area of Primary Interest

General Far East ............... 124

China ..................... 374

Japan .................... 233

Southeast Asia $\ldots \ldots \ldots \ldots \ldots \ldots \ldots . .199$

South Asia .................. 206

Central Asia .................. 9

Korea ...................... ${ }_{18} 8$

Russian Asia ................... 8

East Asia .................... 25

Northeast Asia ............... 59

Middle East .................. 6

Unknown $\ldots \ldots \ldots \ldots \ldots \ldots \ldots .237$

Total $\overline{\mathrm{r}, 498}$ 


\section{Treasurer's Report}

The following is a summary of the audit report for the year ending December $3^{1}, 1959$.

A. Summary of Cash Balances, Receipts, and Disbursements

\begin{tabular}{|c|c|c|c|c|}
\hline \multirow[b]{2}{*}{ General Fund } & \multirow{2}{*}{$\begin{array}{c}\begin{array}{c}\text { Cash Balance } \\
1 / 1 / 59\end{array} \\
\$ 26,902.00\end{array}$} & \multicolumn{2}{|c|}{ Receipts Disbursements } & \multirow{2}{*}{$\begin{array}{c}\begin{array}{c}\text { Cash Balance } \\
12 / 31 / 59\end{array} \\
\$ 37,868.65\end{array}$} \\
\hline & & $\$ 49,876.76$ & $\$ 38,910.11$ & \\
\hline \multicolumn{5}{|l|}{ Special Funds: } \\
\hline $\begin{array}{l}\text { General Expansion } \\
\text { (Ford) }\end{array}$ & $9,512.64$ & -0 & $4,740.19$ & $4,772.45$ \\
\hline $\begin{array}{l}\text { Expansion and Im- } \\
\text { provement of } \\
\text { Journal }\end{array}$ & $2,500.00$ & -0 & $2,500.00$ & -0 \\
\hline Monograph Series & $10,598.26$ & $3,323.37$ & $12,430.24$ & $1,491.39$ \\
\hline South Asia & & & & \\
\hline Committee & $1,126.16$ & $4,582.43$ & $4,894.11$ & 814.48 \\
\hline $\begin{array}{l}\text { Asia Foundation } \\
\text { Lectureship }\end{array}$ & -0 & $8,944.78$ & $8,944.78$ & -0 \\
\hline Committee on & & & & \\
\hline Chinese Thought & 136.28 & $8,368.72$ & $4,600.91$ & $3,904.09$ \\
\hline Asia Foundation & & & & \\
\hline $\begin{array}{l}\text { Travel Grant } \\
\text { Committee on } \\
\text { American Library } \\
\text { Resources on the }\end{array}$ & -0 & $2,500.00$ & -0 & $2,500.00$ \\
\hline Far East & -0 & $6,400.00$ & $5,205.82$ & $1,194.18$ \\
\hline $\begin{array}{l}\text { Committee on } \\
\text { South Asian } \\
\text { Languages: }\end{array}$ & & & & \\
\hline Operations & $2,541.84$ & $6,058.20$ & $5,251.19$ & $3,348.85$ \\
\hline Fellowships & $21,078.18$ & $18,362.13$ & $24,898.20$ & $14,542.11$ \\
\hline Totals & $\$ 74,395.36$ & $\$ 108,416.39$ & $\$ 112,375.55$ & $\$ 70,436.20$ \\
\hline
\end{tabular}

B. Cash Receipts and Disbursements, General Fund

Cash Balance, January 1, 1959

Receipts:

Journal Subscriptions, New

$\$ 3,247.79$

Journal Subscriptions, Renewals..................... $8,754.85$

Membership Dues, New...................... $\quad 4,878.25$

Membership Dues, Renewals...................... $8,898.30$

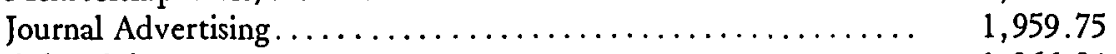

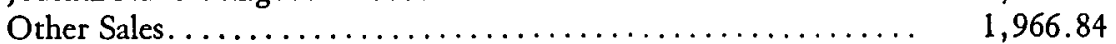

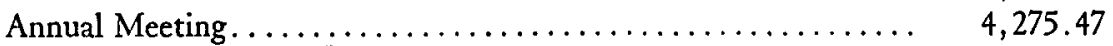

Service Charges Against Special Funds................. $5,182.25$

Interest on Investments............................. 2,288.62

General Expansion Grants (Ford) ................. 4,740.19 
Grant for Expansion of Journal (Ford) $\ldots \ldots \ldots \ldots \ldots \ldots \ldots \ldots, \quad 2,500.00$

Miscellaneous................................... 815.95

Total Receipts.................................. $\quad 49,876.76$

Total Receipts and Beginning Cash....................... $\$ 76,778.76$

\section{Disbursements:}

Journal-publication, editing, misc........... $\$ 22,246.32$

Annual Meeting ...................... 2,825.22

Newsletter........................ $\quad 937.97$

Secretariat....................... 10,205.30

Other....................... $2,695.30$

$38,910.11$

Cash Balance, December 31, 1959

$\$ 37,868.65$

At the business meeting on April 12, Mr. Kublin summarized the above report drawing attention to the surplus of $\$ 1 \mathrm{r}, 000$ in the general funds at the end of 1959 . He reported that this financially healthy condition was likely to continue through 1960 , allowing a budget of
$\$ 47,000$, an increase of $\$ 8,000$ over 1959 ; but he cautioned that the expiration of various special grants in 1961 posed problems for the future. Mr. Kublin mentioned that he was completing six years of service and he extended his thanks to those who had assisted him.
III. Report of the Editor of the Journal of Asian Studies

Mr. Hackett reported a rise in circulation, advertising revenue, and publication costs. As of March 1960, circulation was 2,798, an increase of 687 over the previous year. During the twelve months ending in March, 79 manuscripts were submitted for publication; 15 of these appeared as articles or notes. The following figures indicate the division by area of articles submitted and, in parentheses, those published: Asia (general)-3 (I); China-17 (7); Japan-I5 (4); Southeast Asia-I8 (2); South Asia-2I (4); Central Asia and Korea $-5(0)$. The articles accepted represented various disciplines: History-3; Political Science3; Sociology and Anthropology-2; Language and literature-3; Economics-I; other-2.

The book review section, under the editorship of Rhoads Murphey of the University of Washington, carried I47 reviews between March 1959 and 1960. Geographical areas were represented as follows: general-6; China-40; Japan and Korea-3r; Southeast Asia-15; South Asia-46; Central Asia-9.
Bibliography. Mr. Howard P. Linton served his fifth year as general editor of the Bibliography, issued as the September I959 number. New members of the Advisory Editorial Board are Ralph Braibanti, Alexander Eckstein, Clifford Geertz, E. A. Kracke, Jr., and John Pelzel.

IV. Report of the Editor of the Monographs of the Association for Asian Studies.

Professor Goodrich, the retiring editor, reported that five monographs had been published since March I959. These included Monographs VI-X of the series: Chinese Secret Societies in Malaya. A survey of the Triad Society from 1800 to 1900 . By Leon F. Comber. The Traditional Chinese Clan Rules. By Huichen Wang Liu. A Comparative Analysis of the Jajmani System. By Thomas O. Beidelman. Bangkhuad: A Community in Thailand. By Howard Keva Kaufman. Colonial Labor Policy and Administration, 1910-194I. By J. Norman Parmer. It was stated that the original grants to the monograph fund from the Council on Economic and Cultural Affairs and the Ford Foundation had been exhausted, and that until 
royalties or new grants materialized only one more monograph could be considered. Professor Goodrich announced that Delmer $M$. Brown would be his successor and expressed the hope that new grants would be sought for the continuation of the monograph series.

\section{Other reports presented at the annual busi- ness meeting.}

Report of the Secretary. Mr. Crane first announced that the annual meeting for $196 \mathrm{I}$ would be held in Chicago, March 27-29, at the Palmer House and that the 1962 meeting would be held in Boston. He then announced the recipients of the Rockefeller and ACLS grants for attendance at the International Congress of Orientalists at Moscow, August 9-16, 1960, as follows: Rockefeller Grants-George B. Cressey, W. Norman Brown, John K. Fairbank, Cora DuBois, Derk Bodde, Alexander Soper, Lauriston Sharp, Roger F. Hackett; ACLS Grants-Hyman Kublin, Irene Taeuber, Owen Lattimore, Karl J. Pelzer. Mr. Crane then gave the election results of the 1960 balloting: W. Norman Brown, President, Lauriston Sharp, Vice-President; for Board of Directors: James R. Hightower, Charles O. Hucker, Robert Scalapino, and Milton Singer. The Nominating Committee includes the following: Knight Biggerstaff (Chairman), Donald H. Shively, Phillips Talbot, Ardath Burks, and Richard Lambert.

Mr. Crane presented a summary of the activities of the Secretariat during a year in which membership grew rapidly. One of the special activities of the Secretariat was a session with the chief of the National Defense Education Act in which President Cressey, Professor Ronald Anderson, and Professor John Gumperz expressed the Association's concern and its willingness to help with the program. Other special activities of the Secretariat included the administration of the Asia Foundation Lectureship, collection of applications for the International Congress of Orientalists, and the fiscal administration of the Modern Japan project grant. Professor Crane pointed out that the regular activities of the Association have created a marked increase in the work load, and the necessity of hiring an assistant manager on a part-time basis. He stressed that the immediate and ever-growing function of the Secretariat is to maintain liaison between the Secretariat and the Board in relation to information, policy decisions, etc. Mr. Crane also stated that as academic interest in Asia grows and programs emerge at new colleges there are generated a large number of service, communication, and facilitative functions which the Secretariat is called upon to handle. The Board is aware of this growth in function and will continue to review the long-range implications.

President's Report and Board Actions. Professor Cressey stressed in his report the simple organizational structure of the Association, pointed out the people to whom the Association was indebted for carrying on its various activities, and stressed the fact that this organization is a scholarly one and that all remarks which carry political implications which might be reflected as opinions of the Association, should be ruled out of order. Mr. Cressey then gave a summary of eleven actions taken at the annual Board of Directors meeting on April ro: 1 . The appointment of a Committee on Asian Studies in Secondary Education. 2. The appointment of a Program Review Committee. 3. The decision of the Board to expand the Newsletter in scope and coverage. 4. The appointment of Edward Feitelberg as counsel for the Association. 5. The reappointment of Hyman Kublin as treasurer of the Association. 6. The acceptance of the Ming Biographical Dictionary project as a committee of the Association. 7. The responsibility for preparing a book exhibit with the cooperation of the USIA for the International Congress of Orientalists. 8. The awarding of an honorary life membership to Miss Gussie Gaskill for long and faithful service in preparing the annual Bibliography. 9 . The decision not to sponsor any individual projects, but only project committees. ro. The approval by the Executive Committee at least 24 hours prior to the business meeting of any resolutions put forth at that meeting by officers. Ix. The appointment of an ad hoc committee on library resources on Asia.

Committee on Chinese Thought. Dr. Arthur Wright reported that his committee devoted I959 to two enterprises: seeing through the press two new symposium volumes (Confucianism in Action, published in July 1959, and The Confucian Persuasion, to be published shortly), and searching for new talent for a 
fifth and final conference in September I960, centered on biographical studies of Confucians of different periods. The committee proposes to disband at the end of $196 \mathrm{r}$ on the grounds that after five conferences and "with the completion of five volumes, studies in the history of thought and intellectual history have been pushed as far as is now desirable in the interests of the total development of the humanistic and historical study of China."

Committee on South Asia. Dr. Richard Park outlined briefly the activities of the Committee on South Asia, stating that the committee had met three times in the past year. Three new members of the committee include, Richard Lambert, chairman, Burton Stein, and Phillips Talbot. He also expressed the committee's debt to Dr. O. L. Chavarria-Aguilar in his work as editor of the South Asia Newsletter. Mr. Park went on to outline his new research groups which are scheduled to carry on meetings on the following topics during the next three years: Group on Contemporary Religion in South Asia, Chairman, Edward B. Harper. Group on State Politics in India, Chairman, Myron Weiner. Group on Indian Art History, Chairman, John Rosenfield.

Committee on South Asian Languages. Mr. Crane gave this report in the absence of the new chairman, Professor. Gleason. He stated that eight Indian fellows were supported by this committee for the purpose of studying linguistics in the United States. The committee has had an important function in advising the Department of Health, Education and Welfare and the various universities on the development and operation of the South Asian language programs under the National Defense Education Act, and indications are that this function will continue and may grow in importance. Planning is well along on the compilation of an anthology of translations of modern Indian short stories, and the proceedings of the Committee's first symposium "Linguistic Diversity in South Asia" are now in print.

Committee on American Library Resources on Southern Asia. Dr. Poleman briefly outlined the history of this committee which started in 1957 and which is composed of members from various libraries over the country. The committee is greatly concerned with the implementation of Public Law 480 (the
Dingell amendment), and the budget and program have been worked out and are now before Congress for consideration for support. A proposal is also now before the Office of the National Defense Education Act for a basic bibliography on India and Pakistan. One meeting of the committee will be held in June 1960 with Ford Foundation and AAS support.

Conference on Modern Japan. Dr. John Hall, chairman of this committee, announced that the Committee had received $\$ 135,000$ for a fiveyear program of substantive seminars which will start in 196r. There will be a preliminary conference in Japan in rg6o. The committee hopes to bring some Japanese and European scholars for these conferences.

Program Committee. Professor Eugene Boardman stated that in planning the program his committee had tried to reflect the interests and activities of the Association represented by nine disciplines. It is becoming increasingly difficult to realize this aim, so the Directors have authorized a Program Review Committee to screen the problem. The present committee received a large number of papers and finally organized 35 sessions. Hilary Conroy, the new Program Chairman, will be assisted by Lucian Pye, vicechairman, and eleven other committee members. Advisory Committee on Research and Development. Mr. Crane gave the report of this committee in Professor Lockwood's absence. He emphasized the fact that stress was given to securing additional grants in Asian studies for ACLS, and his committee urged the acceptance of the Ming Biographical Dictionary project by the Association. He stated that the function of ACRD is to strengthen and facilitate the activities of the members, but that ACRD should be related more closely to the Directors and meet once a year in order to function more efficiently. The resignations of William Lockwood and David Mandelbaum were accepted and Douglas Haring and Richard L. Park (chairman) were appointed to fill the vacancies.

Resolutions. Seven resolutions were presented and unanimously accepted by the members present. The text of these resolutions appears in the Association's Newsletter of May 1960.

The retiring president, Mr. Cressey, then presented Professor W. Norman Brown, the new president of the Association. Mr. Brown addressed the group briefly explaining that the 
central purpose of this society was in scholarly pursuits. He stated that few societies show such vigor or so many diverse activities, and he noted that the large number of young people at the meetings augurs well for the Association and for Asian studies in the United States. An investment in the Association is one of return and growth, and the important thing is to make a representation to the foundations for the funds we need, pointing out to them that this group is a good investment. He went on to say that the general policies would remain the same as under his predecessor, Dr. Cressey.

THE PROGRAM OF THE TWELFTH ANNUAL MEETING was arranged by a committee under the direction of Professor Eugene P. Boardman, University of Wisconsin. The following papers were presented at the meeting:

\section{MONDAY MORNING, APRIL II}

The Communist Chinese Economy: Food Production and Agricultural Development. Owen L. Dawson (Former Agricultural Attaché to China and Korea), Riley H. Kirby (United States Department of Agriculture), Yüan-li (Marquette). Institutional Developments in Tokugava Japan. John W. Hall (Michigan), "Origins of the Daimyo"; Ronald P. Dore (British Columbia), "Skill and Intelligence in Tokugawa Society"; Albert Craig (Harvard), "Han Finance and the Meiji Restoration." Chinese Philosophy in the Period of Disunion. Ying-Shih Yu (Harvard), "Correlations Between the Self-Consciousness of the Literati and the New Trend of Thought, A.D. 150250"; Richard Mather (Minnesota), "The Religious Ideas of Sun Ch'o"; Kenneth K. S. Ch'en (U.C.L.A.), "The Role of Ideas in the Persecution of Buddhism in A.D. 574."

Religion and Politics in South and Southeast Asia. Leonard Binder (U.C.L.A.), "The Role of the Fundamentalists in the Constituent Process in Pakistan"; Robert R. Jay (University of Hawaii), "Schism in Tamansari-the Politics of Religion in a Rural Javanese Community"; Richard A. Gard (Yale), "Buddhism and Political Authority in South and Southeast Asia." The Social Effects of British Rule in India. Bernard S. Cohn (Chicago), "The Under Civil Servants and the Changing Social Structure in the Benares Region, I780-1850"; Blair Kling (Pennsylvania), "The Peasantry of Lower Bengal Discovers Its Legal Rights, I859-1862"; Walter Hauser (Chicago), "The Effects of $\mathrm{Na}$ tionalism on the Peasants of Twentieth Century Bihar." Asian-Oceanian Linguistic Relations and Culture History. Ward $\mathrm{H}$. Goodenough (Pennsylvania), "Migrations Implied by Relationships of New Britain Dialects to Central Pacific Language Groups"; Isidore Dyen (Yale), "The Classification of the MalayoPolynesian Languages"; George Grace (Northwestern), "Austronesian Linguistics and Culture History"; Joseph H. Greenberg (Columbia), "Non-Malayo-Polynesian Linguistic Relationships in the Pacific and Southeast Asia."

\section{MONDAY, AFTERNOON, APRIL II}

The Communist Chinese Economy: Economic Development and Industrialization. William W. Hollister, "Output, Investment, and the 'Leap Forward" "; Ta-chung Liu (Cornell), "Economic Factors Prompting the 'Great Leap Forward" "; Feng-hwa Mah (California), "The Finance of Public Investment in Communist China." The Constitution as an Issue in Current Japanese Politics. Robert M. Spaulding, Jr. (Michigan), "Proposals for a Third Japanese Constitution"; John M. Maki (Washington), "The Constitutional Investigation Commission, a Practical Approach to Revision." Sino-Soviet Relations: The Borderlands. Paul Hyer (Brigham Young), "Lessons from the Japanese in Mongolia and Tibet"; Allen S. Whiting (Rand Corporation), "Sinkiang in Sino-Soviet Relations"; Theodore Shabad (New York Times), "Industrial Development of the Sino-Soviet Borderlands"; George Murphy (Stanford), "Politics and Economic Planning in Central Asia."

Form and Content of the Social Novel in Modern Indian Literature. Naresh Guha (Jadavpur University, Calcutta, and Northwestern), "The Social Novel in Bengali Literature"; Prabhakar Machwe (Sahitya Akademi, New Delhi, and Wisconsin), "The Social Novel in Hindi Literature"; C. M. Naim (California), "The Social Novel in Urdu Literature." China Area Specialist Session. Bernard Gallin (Cornell), "Matrilateral and Affinal Relationships of a 
Taiwanese Village"; Ramon H. Myers (University of Hawaii), "The Role of Agriculture in the Economic Development of China's Northeast, 186I-1945"; Sidney Klein (Rutgers), "Land Reform Policies of the Chinese Communist Party, 1928-1959: An Economic Analysis."

\section{TUESDAY MORNING, APRIL I 2}

Recent Developments in Taiwan. David N. Rowe (Yale), "Farmers' Associations and Political Developments in Taiwan"; Sho-chieh Tsiang (International Monetary Fund), "Taiwan's Economic Development in Recent Years"; Richard L. Walker (South Carolina), "Taipei's Conduct of Diplomacy." Non-Democratic Factors in South and Southeast Asian Politics. Rupert Emerson (Harvard) "Erosion of Democracy"; Milton Sacks (Haverford), "NonDemocratic Party Developments"; Lucian Pye (M.I.T.), "The Increasing Role of the Military"; John Badgley (California), "The Absence of Intermediary Levels of Authority." China Area Specialist Session. Robert M. Marsh (Michigan), "Official Advancement in the Ch'ing Bureaucracy"; Miss Li Chi (California), "An Interpretation of the Classical Tradition in Chinese Poetry"; Paul A. Cohen (Harvard), "The Anti-Christian Tradition in China."

Foreign Aid and the Third Five-Year Plan in India. I. G. Patel (Embassy of India), "The Determinants of Economic Expansion in India"; Britton Harris (Pennsylvania), "Urban Growth, 196I-1966: Implications and Alternatives"; Morris Opler (Cornell), "Pressures and Responses in Rural India." Aspects of Japanese Drama. Frank Hoff, Jr. (Harvard), "The Image as a Dramatic Constituent of the No Play in Sotoba Komachi"; Donald Keene (Columbia), "Chikamatsu's Plays and the Puppet Stage"; Donald H. Shively (California), "Kabuki and the Culture of Cities"; Ted T. Takaya (Columbia) "Mokuami and the Early Meiji Period." Specialist Session-Philippines and Ryukus. Douglas G. Haring (Syracuse), "Black Sugar in Amami Oshima, Northern Ryuku Islands"; Samuel N. Seidman (Rutgers), "Entrepreneurship and Economic Changes in the Philippines"; Sheldon Appleton (Michigan State), "Overseas Chinese and the
Development of Democracy in the Philippines"; William P. Lebra (Pittsburgh) and Thomas W. Maretzki (Connecticut), "The Village Cooperative in Okinawa."

\section{TUESDAY AFTERNOON, APRIL I2}

United States Far Eastern Policy: An Appraisal. Russell H. Fifield (Michigan), "Southeast Asia and the Philippines: The Future of SEATO"; Douglas H. Mendel, Jr. (U.C.L.A.), "American Policy and Japanese Security"; Harold M. Vinacke (Cincinnati), "The United States, Communist China, and Taiwan." rgth and 2oth Century Missionary Approaches in China. M. Searle Bates (Union Theological Seminary), "The Success of Missionaries in Adapting to Chinese Culture and Society"; K. C. Liu (Harvard), "Current Research on the Missionary Movement"; Theodore Herman (Colgate), "Western Missionaries as Agents of Economic Change in China." The Political Modernization of China. Chun-tu Hsüeh (Stanford), "Study of the Controversy on the Founding of the Hsing Chung Hui"; Y. C. Wang (Dickinson College), "Western Impact and Social Mobility in China, rgoo-1949."

Tibet-Substance and Shadow. Robert B. Ekvall (Washington), "Tibetan Cultural SelfConsciousness"; Beatrice D. Miller (Wisconsin), "The Web of Monasticism"; Turrell V. Wylie (Washington), "A Visit to the Dalai Lama." Modern Japanese Literature and its Problems. Yoshio Iwamoto (Michigan), "Translations of Foreign Literature in Japan"; Marleigh Ryan (Columbia), "Futabatei Shimei and the Early Meiji Novel"; Edward Copeland (Minnesota), "The Dissolution of the Ken"yusha: A Brief Comparison Between Ozaki Koyo and Yamada Bimyo." Specialist SessionKorea. Key P. Yang (Library of Congress), "North Korea as Seen Through Its Publications"; Robert A. Scalapino (California), "The Early History of the Korean Communist Movement"; Philip Rudolph (Richmond Research Corporation), "North Korea's Political and Economic Structure"; Clarence N. Weems (Fairleigh Dickinson), "The Korean Independence Movement from Versailles to Tokyo Bay (1919-1945)"; Kyung Won Lee (Charleston Gazette), "Authoritarian and Liberterian Concepts of the Press in the Post-War Korea." 
WEDNESDAY MORNING, APRIL I 3

Economic Growth and Political Stability: The Experience of Free Enterprise. Frank H. Golay (Cornell), "The Role of Private Initiative in Post-War Philippine Economic Growth"; Warren S. Hunsberger (International Cooperation Administration), "Aspects of Economic Growth in Contemporary Japan." National Unity in South and Southeast Asia. Keith Callard (McGill), "National Unity in Pakistan: The Strength of an Idea"; W. Howard Wriggins (Library of Congress), "The Problem of $\mathrm{Na}$ tional Unity: An Analysis Based on Ceylon's Experiences"; Gerald S. Maryanov (Illinois), "National Unity and Regional Protest in Indonesia: An Interpretation"; Selig Harrison (The New Republic), "India: The Imbalance of the Union." Warlordism and Militarism in Twentieth Century Chinese History. Donald Gillin (Duke), "Yen Hsi-shan"; Akira Iriye (Harvard), "Chang Hsüeh-liang and the Japanese, 1928."

Urban Politics in a Plural Society. Henry C. Hart (Wisconsin), "Bombay"; Lloyd I. Rudolph (Harvard), "Madras"; Myron Weiner (Chicago), "Calcutta." Factors of Stability and Change in the Modern Japanese Community. John B. Cornell (Texas), "Local Group Stability in the Japanese Community"; Erwin H. Johnson (Rhode Island), "Perseverance Through Orderly Change: The 'Traditional' Buraku in a 'Modern' Community"; Edward Norbeck (California), "Post-War Economic and Social Changes in Northeastern Japan." Specialist Session-Southeast Asia. Millidge P. Walker (California), "The Indonesian Republic-Decentralization in a Guided Democracy"; George Modelski (Chicago), "Australia and SEATO”; Lt. Col. A. A. Jordan, Jr. (U. S.
Military Academy), "The Strategy of American Military Assistance in South and Southeast Asia."

\section{WEDNESDAY AFTERNOON, APRIL I3}

Economic Growth and Political Stability: The Experience of Mixed Economies. Benjamin Higgins (Texas), "Entrepreneur and Elite in Indonesian Development"; Bert F. Hoselitz and Myron Weiner (Chicago), "Economic Development and Political Stability in India." History of Southeast Asia. John F. Cady (Ohio), "Empire and Trade in Early Southeast Asia"; D. G. E. Hall (London), "On the Study and Teaching of Southeast Asian History" (read by Harry J. Benda, Yale). Interstate Relations in Asia. William Johnstone (Johns Hopkins), Sudershan Chawla (Muskingum), "Tibet, a Case Study of the Indian Concept of National Interest"; John Tsu (Seton Hall), "Asian Bloc in the UN"; Djang Chu (formerly School of Advanced International Studies), "Historic Chinese Territorial Claims in Asia." Specialist Session-Japan. Donald F. Lach (Chicago), "Japan in the Eyes of Europe: The Sixteenth Century"; George H. Kakiuchi (Washington), "Nonaka Kenzan and Early I7th Century Tosa"; John Young (Georgetown), "The Research Department of the South Manchuria Railway Company." Specialist Session-South Asia. William L. Rowe (Cornell), "The Inner Meaning of Urban Migration for North Indian Villagers"; Edwin D. Driver (Massachusetts), "Differential Fertility in Central India"; Brijen K. Gupta (Southern Illinois), "Indian Bureaucracy Under Gupta, Mughal and British Empires-A Comparative View"; Khalid Bin Sayeed (New Brunswick), "The Genesis of Pakistan." 